recent vears. The chapter on hormones contains no mention of the adrenal gland, let alone the steroidal hormones of this gland which have excited so much interest in recent years-the sole entry in the author index to Kendall refers to his early work on thyroxine, while that to Reichstein refers to work on vitamin C. Chapters on porphyrins and azaporphyrins are good, and the latter probably gives the first collected account of the phthalocyanines. The chapter on "Synthetic Polymers and Condensates", in opening with "These substances may be viscous liquids, hard and glass-like or amorphous rubber-like solids", gives little hint of the important uses fibrous polymers have found in the textile industry, and the existence of nylon is only mentioned in the last sentence in the chapter. The chapter on "Rubber" might be expected to give some account of the spectacular developments during the Second World War of synthetic rubbers, but instead gives a long account of the controversies over the polymerization of isoprene during the first decade of this century that led up to the synthetic product of the First World War. The brief chapter on "Some Deutero-Organic Compounds" might well have been expanded into an account of the labelling of atoms in general, in organic compounds, both by 'heavy' and by radioactive isotopes, and their use in elucidating the mechanisms of biological and non-biological chemical reactions. A chapter on "Some Cases of Isomerism in Cyclic Compounds" gives an account of the early work on the geometrical isomerism of fused ring systems, for the case of the decalins, but fails to bring out the fundamental connexion this has with optical isomerism and ignores the work of Hückel and of Linstead during the 1930's. A chapter entitled "The Diphenyl Problem" gives a good account of the early work that led up to the recognition of stereoisomerism due to restricted rotation as a general phenomenon. In "Some Aspects of Stereochemistry" the optical activity ascribed to nitroparaffin salts is now known to be non-existent. A chapter entitled "Other Cases of Abnormal Valency" deals with what would now be described as free radicals of long life, although the better-known triarylmethyl type is not described, and the existence of such radicals is not regarded as proved-" "Once the conception of free radicals is admitted, the long-tried dogma of the quadrivalency of carbon comes into the scales for a final test". The opening sentence of the chapter entitled "Some Applications of Electronics to Organic Chemistry" clearly indicates that only the ideas of the first quarter of this century are considered, and that there have been developments since is only hinted at in a footnote. Vol. 3 concludes with chapters entitled "Structural Formulæ and their Failings" and "Some Unsolved Problems", which having served their purpose in earlier editions might well have been omitted from this edition.

It is not clear to the reviewer the purpose these volumes are intended to serve. The advance of organic chemistry is so rapid to-day that successive editions of a book of this type, particularly after an interval of nearly twenty years, would be expected to contain largely fresh topics, the material of the previous edition having by then been incorporated into text-books. Certainly the sections on theoretical topics are inadequate if not misleading; their deletion would give room to bring those on natural products up to date. Then, with the fuller detail thus given, these volumes would be of value to students in providing a bridge between the necessarily abbreviated accounts in general text-books and the terseness of the "Annual Reports" or the "Quarterly Reviews" of the Chemical Society.

In general, the author index does not discriminate between authors of the same sumame, and the reviewer disclaims credit for most of the work ascribed to him.

S. H. HaRPer

\section{THE BOOK OF A BIRD-LOVER}

\section{In Praise of Birds}

By Dr. Charles E. Raven. Pp. $206+17$ plates. (London: George Allen and Unwin, Ltd., 1950.) 15s. net.

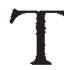

HE publication of this book, with its title of great charm, is something of a landmark, because it is a selection of some of the best bird papers which the gifted author has published during the past twenty-five years, enriched by some capital photographs. Among the illustrations, surely the most remarkable is that of a long-tailed drake in summer plumage, photographed in June, off Scourie, on the north-west coust of Scotland. To see, let alone to approach so near as to be able to photograph, a bird of the Arctic in June in British waters is unusual. That small drake must have been exceptionally tame, for it was obviously photographed at close range.

From Texel, with its wonderful population of wading birds, we follow the author northward, or more correctly north-west, to the rocky fastnesses of Foinne Bheinn and Areuil (had the book been about animals, we might have been told about the legendary fork-tailed deer of Arcuil) in the remote Reay Forest, home of the golden eagle, of the green shank and of the black-throated diver. (The black throated diver did not nest until June this year, and, as almost always, lost her two eggs through her small nesting island being submerged by a sudden rise in the level of the loch, following on a day of heavy rain.) In the Reay Forest the author had an adventure with a golden eagle. It was only this summer that I was told by John Scobie, the hero of the tale (he spells his name, by the way, with only one 'b'), further details of that adventure, and he pointed out the rock on which the eagle nested on that occasion-the great bird does not now occupy that site, although it is still in the neighbourhood and was seen to carry to another eyrie a full-grown heron. The author (p. 199) asks why the common heron, obviously a marsh builder, should nest in trees. This has always puzzled me, and when on the Hebridean island of Colonsay I was shown a heron colony in the reeds of a loch, I thought how much more in keeping with their surroundings were the long-necked and long-legged birds there than on the tree tops where, on the mainland of Britain at all events, the species habitually nests.

When the author asks whether a bird may not perhaps have psychic sensitiveness, he finds himself in sympathy with the reviewer of his book, for it is unlikely that the human race should have the monopoly of psychic awareness.

"In Praise of Birds" is packed with good things. The style, as might be expected, is simple yet vivid; and the reader finds himself being held by one chapter after another, so that he lays aside the book with reluctance.
SETON GORDON 